\title{
Study of Ecological Change in Modern Engineering-Geological Condition of Baku Mould
}

\author{
Allahverdi Gizi ME* and Galandarov Bahadir H \\ Geological Faculty, Baku State University, Azerbaijan
}

*Corresponding author: Mammadova Esmiralda Allahverdi gizi, Geological Faculty, Baku

Review Article

Volume 4 Issue 3

Received Date: March 12, 2020

Published Date: April 13, 2020

DOI: $10.23880 /$ jenr- 16000197 State University, Baku City, Z Khalilov street, 23, Azerbaijan, Tel: +994503649648; Email: m.esmiralda@yahoo.com

\section{Abstract}

The modern engineering-geological condition of Baku mould was explored. It was determined of the dangerous geodynamic processes in the zone of Baku mould depends on geological environment which fixed the peculiarities of their dynamics and kinds of the processes. These processes in the mould zone (especially landslides) are activated by increase of the technogen influence on geological environment at present.

The physico-mechanic features of the different rock were studied, the reasons for exogenous geological processes were investigated, and the opportunities of construction of engineering-installations on the same rocks were evaluated. After all, some protective measures were suggested for inhibition of activation in sliding process.

Reports of the National Geological Exploration Service of the Ministry of Ecology and Natural Resources of the Republic of Azerbaijan and the authors' personal observation data were used.

Keywords: Sliding Process; Rock; Engineering-Geological Condition; Antropoghenic Factors; Mould; Exogenous Geological Process

\section{Introduction}

At present Baku city is considered one of the industrial and cultural centers which intensively develop in the region: a zone of the city expands, new metro stations are under construction, the number of residental and industrial microdistricts is increasing, reconstruction of the central part of the city is realized, decentralization of industrial enterprises which adversely affect the city's environmental situ-ation is intended [1].

The centuries-old history of Baku city confirms a large development of the dangerous geological and engineeringgeological processes in its zone. These processes complicate the economic development of the territory and reduces the reliability of the operation of buildings and installations. From this point of view, it is important to study an engineeringgeological condition of the city comprehensively and this can be the basis for geological component validation of the main plan of the city in future.

The geological environment of Baku mould was selected as a research object.

An aim of the work consists of investigation of the ecological change occurring in engineering-geological condition under different factors effect and submission of relevant proposals at present. The problem was solved by summarizing the data collected on field, laboratorial, cameral engineering-geological research, engineering-geological test and using of the methods of the analysis, field research results [2].

\section{Analysis and Discussion}

Baku mould is geomorphologically plateau and sediment 


\section{Journal of Ecology and Natural Resources}

of the 4th period is on the Absheron sediments.

The initial relief of Baku plateau was complicated by terraces possessing of different hypsometric height formed as a result of the Caspian sea transgression, also denudation, antropoghenic, defliation, abrasion-accumulative processess in the 4th period. Baku plateau has semicircle structure, and it is inclined towards Yasamal, Chakhnaglar-Boyukshor, Bulbula-Zigh valleys.[3]

A role of the antropoghenic factors is great in formation of the modern relief of mould. A total area of the mould is $135 \mathrm{~km}^{2}$. The subsoil waters widespread in the zone. Their bed depth is from $0,2 \mathrm{~m}$ (in the coastal zone) to $60-70 \mathrm{~m}$ (away from the coast). The flow direction of the subsoil waters directs towards the sea.

As it is known the geological structure, relief, climate, hydrogeological and engineering-geological condition, including tectonic movements naturally form the basis of exogenous geological processes. An effect of the technogen factors plays a leading role in spreading and development of the exogenous geological processes because Baku and Absheron are developed economic regions in our republic. We should note that the development temp increased for some times under an influence of the human's economic activity at present, while the exogenous geological processes occur gradually during geological periods in the zone of Baku mould.

The landslides more than exogenous geological processes developed in the city. The landslides in Baku are periodically activated and this activation is due to rising underground water level as a result of accidents on water-sewer pipelines of the city. So, as in all economically developed cities in Baku the urbanization process intensively develops and it is clear that this process is followed by expansion of town-building complex. If by the year 2000 there were approximately 2,0 million people in the town's official census, this figure was already over 2,5 million. If over the last 20 years there has been a half-million population growth, then the population has been provided with new apartments, and those new apartments have been connected to the old system of water supply for a population of 2,0 million, resulting in additional overload and damage to communication system. Losses caused by damaged communication systems are used to feed groundwater directly. Lack of centralized indoor sewerage in some parts of the city may exacerbate the problem [4].

On the other hand the engineering-geological condition of the zone should be exactly studied; any kind of building should be performed according to the norms during the town-building. While not following the building norms, the zone endurance is violated, the complications arise, and liquidating these complications requires a lot of funds. Removal of the lower slopes, violation of dynamic balance at the expense of the buildings on the upper parts and so on technogen factors lead to activation of soil displacement.

The landslides of the city have been noted in the north ("Binagadi" sliding zone), south-west ("Bayil" projection, "Bayil", "Park" sliging areas) and east ("Zigh" and "Ahmadli" sliging areas) parts of Baku mould.

The greatest sliding is considered Bayil sliding. The Bayil sliding occupies 4,5 hectares area between Neftchilar avenue and "Eternal Flare Com-plex" of Alley of Martyrs. This sliding was very active in 2000 , surrounded 20 hectares of the area and condition was created for sliding expansion. The activity increased even more in 2018. At present an area of sliding on the Bayil slope is $12-13 \%$, a bulky of the landslide increased $15-20 \%$. In some places the width of the cracks is 1 meter and the depth is 10 meters. The Bayil sliding area is mainly characterized by the slope possessing inclined and steep bed and it is situated in the zone where the ravines are dense [5].

In the sliding area as a result of development of the exogenous geological processes the fractures and sediments have been created. As it is a foothill zone, the ravines cover most of the area, sometimes their length reaches $60-70 \mathrm{~m}$. Formation of these ravines in different directions made the area more uneven form. An activation of the sliding processes was a reason for creation of deformations in some houses, industrial and welfare objects, the asphalt pavement became completely useless. The researches show that a main reason for this process is presence of a certain section of the field with an up-right bed, presence a lake in the low part of the slope and geological strukture of the zone. One of the impact factors on sliding process is atmospheric precipitations. The activity incre-ases in the sliding area in spring and autumn.

The physico-mechanic characters of the rocks were studied by the National Geological Explo-ration Service of the Ministry of Ecology and Natural Resources in Azerbaijan. Colluvial $\left(\mathrm{CQ}_{4} \mathrm{Yhz}\right)$ sediments consist of clay, clayey sand, mass mixed with the rock crumbs in different size. Density of these sediments changes by $0-4 \mathrm{~m}$.

Lake-solonetz sediments ( $\mathrm{gsh}_{4} \mathrm{Yhz}$ ) are found in the closed depressions. They consist of grayish clayey sands and clay with lithologically strong saline sand layers. It is impossible to per-form construction works in the areas where these sediments with density not more than 1,5-2,0 m spread. Eluvial-deluvial sediments $\left(\mathrm{edQ}_{4} \mathrm{Yhz}\right)$ surround the slopes. They are formed from the heavy clayey sands with lithologically limestone and sandstone.

A quantity of salts which are solved in the water is 0,174 


\section{Journal of Ecology and Natural Resources}

$\mathrm{g} / \mathrm{l}$, chemical composition of subsoil waters is chloric-sulfate. The sandy rocks which form an upper part of the aeration zone have high (1,8-6,3 m/day) filtration coefficient.

We should note that eluvial-deluvial sediments are aggressive againist concrete and metal constructions because they possess humidity and saltness to the extent that can grenerate corro-sion processes. These rocks are often subjected to exogenous geological processes and sliding, depositing, landslide-remnants, gully creation, suffocation and other processes occur in them because they have weak stableness and strong weathering. Therefore it is considered useless to construct the engineering-devices on sediments of eluvial-deluvial origin.

Upper hemisphere of eopleytocene $\left(Q_{0} a_{3}\right)$ is formed of limestone, layered clay, heavy clayey sands, fine-grained sand, medium-sandy clay, the sediment complexes consisting of their shift. The Upper Absheron hemisphere on the zone is revealed by the wells and on the surface. Little stells and sometimes appendixes of the weak sandy limestones are observed on the upper part, these rocks are complicated by the fissures, deformations in the most parts. Hardness of physico-mecha-nical characters and thickness cause their durability against exogenous processes.

The Upper Absheron rocks lie at 10 angle in the 10$40^{\circ}$ north-eastern direction. Their thic-kness is from $3,5 \mathrm{~m}$ to $40,0 \mathrm{~m}$. On the cut lensing, folding and swelling at 2,0 m density were ob-served. The Upper Absheron sediments were subjected to strong structural change in Baku mould. In this zone the limestones are inclined to $280-290^{\circ}$ of southwest, they are observed by the fissures at $70-76^{0}$ angle.

The clayey combinations concerning the Upper Absheron hemisphere are found by the appen-dixes to the surface and they are situated under the part of the eluvial-deluvial rocks, their total thickness is $10-15 \mathrm{~m}$. Porosity of rocks is observed in $32-38 \%$ interval, and by $14-22 \%$ natural moisture. Being of the inter-nal friction $20^{0} 13-26^{0} 19$, cohesive force $0,38-0,47$ shows their weak physico-mechanic characters. Stratification, dislocation, coinciding of the stratification with the Earth's surface inclination increase their sliding danger. The researches show that static level of the underground waters is $0,8-23,6 \mathrm{~m}$, mineralization deg-ree is $1,4-12,6 \mathrm{~g} / \mathrm{l}$, consumption of the wells is $0,05-0,45 \mathrm{l} / \mathrm{c}$ and a filtration coefficient of the watery rocks changes 1,17-2,91 m/day. According to the chemical composition the waters change from hydrocarbonate-calium type till chlorine-natrium. Nourishment of underground waters mainly occur at the expense of the sources with tech-nogenic origin.

The reasons of the sliding process which were studied in the area of research have been in-vestigated. So it was defined that a main reason of the sliding upright cutting of slope about 80 degress in the process of brick factory operation, creation of the fissures with the different direction on cut clayey rocks of the slope and exposing to weathering process, presence of the water source affecting their durability and ponds of sewage waters. The danger of the exogenous geological processes activation is higher in the zone. Addition to Bayil sliding the landslide happened in Badamdar in December of 2012. The reason as flowing of waters from water-sewerage lines to the slope. The sliding event was noted on the east slope of Badamdar plateau. A width of sliding is 180-220 $\mathrm{m}$, length is $250 \mathrm{~m}$, but a visible depth of fissure is $4-5 \mathrm{~m}$. The based measures have been taken against sliding. But at the beginning of 2020 the activation of sliding has been observed. Sliding covers a large area. The width of the sliding land layer is $200-250 \mathrm{~m}$, density is more than 20 meters. The activity was observed in the field of "Teletower" of the Sabayil district according to the information of the National Geological Exploration Service of the Ministry of Ecology and Natural Resources in Azerbaijan republic "About a state of the areas exposed to the exogenous geological processes in the Republic" in February of 2018. The length of sliding area is $200-220 \mathrm{~m}$, width is $100-130 \mathrm{~m}$, crac-king layer height is 5-12 m.

The sliding process occuring on the slope between N.Tusi and Ganja avenue in 1988 deve-loped and created danger for the residental buildings. Recently, the observations show increase of tension on the slope was revealed from the beginning of 2000 . So, the hollows with the kars type and the depth of 1,7-2,2 m were developed.

The eluvial-deluvial clayey sands possessing 5-11 m dense and limestones of Middle Abshe-ron forms the basis of the sliding mass. The activity isn't noted in Ahmadli- 1 and Ahmadli-2 sliding areas of the Khatai district. At present a relative stability continues in the area.

The following measures are considered expedient taking into account the possibility of peri-odic activation of the sliding processes in Baku mould:

- Observance of the subsoil use rules;

- Prevention of water losses from all the communication systems in the zone, building closed se

- Werage systems in the necessary places and following the building norms;

- Exclusion subsoil waters by drainage in the sliding area;

- Planting of the bushes and trees resistant to thirst on the slope and so on.

\section{Conclusion}

- Though naturally occuring exogenous geological processes are geological structure, neotectonics, 


\section{Journal of Ecology and Natural Resources}

engineer-geological and hydrogeological conditions, and climate, in modern times these processes have been intensified by incresing technological impact on the geological environment;

- Eliminating the cause of the sliding process is easier and less costly than eliminating the con-sequences of the sliding;

- It is impotant to take the recommended protective measures in view of the high pro-bability of sliding activation in the future.

\section{References}

1. Abadov BA, Mammadova EA (2012) Salt composition of the underground waters and rocks of the aeration zone in the Absheron peninsula. The Republic scientific Conference materials on a topic "Actual problems of geology" which was dedicated to Haydar Aliyev's 89 th Anniversary. University publishement, Baku, pp: 150-
152.

2. Alakbarov AB (2000) Absheron: problems of hydrogeology and geoecology. Baku: Kraton, pp: 482.

3. (2008) Geology of Azerbaijan, Vol.VIII, Hydrogeology and engineering geology. Pub. Nafta-Press, Baku, pp: 380.

4. Mammadova EA (2018) Legitimacy of the regime formation of the underground waters of the urban zones: in the sample of Baku city. American Journal of Science and Technologies. №1, Princeton Univercity Press10: 259-267.

5. Mammadova EA (2019) Analysis of the condition of formation of the modern hydrogeoecological processes in Baku and its surroundings territories. Journal of Geography and Earth Sciences 7(1): 45-48. 